\title{
Entrepreneurship Competence and Motivation to Improve Business Performance
}

\author{
Hari Mulyadi ${ }^{1,{ }^{*}}$ Eded Tarmedi ${ }^{2}$ P. Purnamasari ${ }^{3}$, Yusuf Murtadlo $\mathrm{H}^{4}$ \\ ${ }^{1}$ Universitas Pendidikan Indonesia \\ ${ }^{2}$ Universitas Pendidikan Indonesia \\ ${ }^{3}$ Universitas Pendidikan Indonesia \\ ${ }^{4}$ Universitas Pendidikan Indonesia \\ *Corresponding author.Email: harimulyadi@upi.edu
}

\section{ABSTRACT}

This study aims to examine the effect of entrepreneurship competence and motivation to improve business performance.

Keywords: Entrepreneurship Competence, Motivation, Business Performance.

\section{INTRODUCTION}

Competition in a business has become a problem these days. One influential factor that could lead to the win of a business game is a good performance. Performance describes the results gained by an organization both in the form of profit-oriented or nonprofit-oriented produced during a time [1]. As stated by Armstrong and Baron, performance is the result of work that has a strong relationship with an organization's strategic goals, customer satisfaction, and economic distributions [2].

This type of performance can be divided into economic performance, producing superior products and measurable workability. In addition, the problem of business performance is generally experienced by new businesses that plunge into entrepreneurship, such as MSMEs or the creative economy [3].

Micro, small and medium enterprises (MSMEs) are important parts of the economy of a country or region. This important role has encouraged many countries, including Indonesia, to continue to develop MSMEs. Although it has small number of workers, assets and turnover, the role of MSMEs is quite important to support the economy. There are three underlying reasons for developing countries to consider the importance of MSMEs. First, the performance of MSMEs tends to be better at producing productive workforce. Second, as part of its dynamics, MSMEs often achieve increased productivity through investment and technological change. Third, it is frequently believed that MSMEs have advantages in terms of flexibility rather than large businesses [4].

The development of MSMEs becomes a supporting factor in increasing various types of businesses, both in the micro, small and medium categories, such as in the city of Bandung. Apart of being known as the flower city, it is also known as the city of artists. This can be seen from different stores that sell painting products, traditional Sundanese musical instruments and one of Sundanese traditional musical instrument craftsmen, such as angklung in Saung Angklung Udjo. It attracts some foreign and domestic tourists who visit to buy angklung souvenirs and enjoy angklung music shows.

Through the development of the MSME sector in Indonesia, especially in the city of Bandung, the enactment of Law No.20 of 2008 concerning Micro, Small and Medium Enterprises (MSMEs) on July 4, 2008, Indonesia has a more complete definition of MSMEs compared to the definition in the old law, namely Law No.5 of 1995 which defines only for Small Businesses. This definition is based on business criteria, namely assets or wealth and annual sales.

It can be seen from various empirical data that support that the existence of MSMEs. They are quite dominant in the Indonesian economy (KUKM), Indonesia is one of the countries that has a very high growth in MSMEs. 
The development of MSMEs in Indonesia continues to increase from year to year. It is related to government efforts that need to support MSMEs by facilitating business making and providing assistance from the capital and other needs, especially now that Indonesia has entered the market ASEAN global (MEA) with tough competition facing outside entrepreneurs who sell foreign products to Indonesia. Business Performance is crucial in increasing production and quality, so it needs to be improved so that Indonesia does not lose to other countries in the face of MEA.

Before proceeding to the World Market or Global market, it is better to fix the local market in the provinces in Indonesia. West Java Province, MSMEs also have a very important role in the economy. Furthermore, in West Java Province, MSMEs have experienced quite good developments, both in terms of business units and the absorption of their workforce.

The development of MSMEs in West Java Province has increased both in terms of business units and workforce. In terms of business units, they have increased every year, namely, in 2014 the number of MSMEs in West Java Province was 8,524,494 units, in 2015 it rose to 8,730,254 units, and in 2016 also increased to $8,750,914$ units. Furthermore, in terms of the workforce also experienced Kenikan. In 20014 West Java Province MSMEs were able to absorb 13,542,296 workers, in 2015 it increased to 13,966,311 people, and in 2016 it increased again to $14,278,402$ people [5].

So, it implies that the development of MSMEs in West Java Province every year has always increased, both in terms of business units and the absorption of their workforce. It indicates that the climate of MSMEs in West Java Province has a better prospect to be developed in the future to be able to overcome the problem of income distribution in the community.

From 2014 to 2016 the Bandung trade industry, especially in micro-businesses has a declining development, both in terms of business units, labor, assets, and turnover. It is that the development of the trade industry and creative economy in the city of Bandung has problems that must be handled by the parties involved in it [5].

The roles of the creative economy are partly important in advancing Indonesia, starting from providing economic contributions to strengthening the identity of the nation. It also preserves natural resources (PNR) and cultural resources to give a social impact for people to love and be proud of using products made by the nation itself [6]. When the researcher was doing prestudy, she found a problem in MSMEs, especially in the angklung souvenir trade in Saung angklung, Udjo, Bandung.

I In 1966 Saung Angklung Udjo was established. During this journey, the business of angklung craftsmen was still not so much in demand. However, over time, more people became familiar with angklung and made public awareness grew. It was important to preserve one musical instrument traditionally owned by this nation overtime because it grows a business. Just as in the angklung country, it also turns out to be an attraction for foreign tourists whether it is in the form of angklung performance or even making the angklung itself a souvenir for both family, relatives, work colleagues/business, partners. These problems include the development of sales obtained each year has decreased.

Table 1 Sales of souvenir angklung saung angklung udjo of bandung city 2014-2017

\begin{tabular}{|l|l|}
\hline \multicolumn{1}{|c|}{ Years } & \multicolumn{1}{c|}{$\begin{array}{c}\text { Souvernir } \\
\text { (Angklung) }\end{array}$} \\
\hline 2014 & 14.236 \\
\hline 2015 & 12.797 \\
\hline 2016 & 7.573 \\
\hline 2017 & 3.602 \\
\hline \multicolumn{2}{|c|}{ Source: Data is obtained from Saung Angklung Udjo Marketing Manager, 2018 }
\end{tabular}

Based on Table 1, obtained from the interviews, it can be seen that the sales of souvenirs in Saung Angklung Udjo Bandung decreased every year where the lowest sales were in 2017 of 3,602 while sales in 2016 amounted to 7,573 Souvenirs were obtained from the total sales of various types of angklung: mini angklung 8, angklung Sarinade 8, angklung sarinande units, angklung sarinande plus 14.

To see the existence of business performance problems on capital growth indicators, the marketing manager Saung Angklung Udjo was interviewed but Saung Angklung Udjo did not provide nominal information, the information provided by Kang Maul as Marketing Manager was the initial capital of SAU (Saung Angklung Udjo) to angklung production and SAU's physical development and SAU made a partnership program to produce angklung in 1966 of $\mathrm{Rp}$. $20,890,000.00$. In the period of 2010 until now, the costs or capital incurred increased for angklung production; employee salary; SAU care and development; promotion; creative program; and socio-cultural programs. In 2014 the capital increase was $89 \%$ from the initial capital, in 2015 it fell $13.8 \%$ from 2014, in 2016 to 2017 there is a decline in percentage from the previous year reaching $39 \%$. $58.3 \%$ of the profit was obtained from artistic performances. Apart from the appearance and sale of angklung souvenirs directly, profits are also obtained from ordering angklung with online marketing. Angklung sales online from 2014 to 2017 experienced a fluctuating order change, the units in selling angklung were sold per SET not unit. The decline in 2017, namely angklung sarinande 8 from 1506 to 791 sets, ordered, the price of per-set angklung sarinande 8 was Rp. $283,000.00$, each year the order decreased by $52.5 \%$ from 2014 to 2017. 
The visit to SAU (Saung Angklung Udjo) also affected the selling of angklung souvenirs in Saung Angklung Udjo. In recent years the visit to SAU has seen an increase, but in 2017, the number of visitors has dropped from the previous year of 269,493 (for domestic visitors and Foreign) to 134,747 in 2017 , according to Kang Maul as Marketing Manager. SAU's visitors are predominantly students, for international visitors, the number has declined until 2017 now (Information from the Marketing Manager, Kang Maul). At present there are still some obstacles faced by Saung Angklung Udjo in making angklung sou-venirs and his own angklung musical instruments, among them is the lack of craftsmen and raw materi-als for making angklung according to Operational Di-rector Saung Angklung Udjo. So far, the raw material for making angklung in Saung Udjo has only been obtained from the Leuweung Awi area, which has limited production capacity.

There are problems with business performance on labor growth indicators. Based on the initial survey in Table 1 there was a decrease and increase in the Saung craftsmen Angklung Udjo every year. This is related to the craftsmen themselves who are more focused on hard work and more focused on capital if many orders for making angklung can generate income for each craftsman around Rp.2,000,000 to Rp.3,500,000 rupiah per week (Information from craftsmen SAU angklung), the problem is the lack of confidence of angklung souvenir craftsmen in maintaining their business to grow and be better.

Information obtained from Kang Yana as Production Manager of Saung Angklung Udjo, that in mak-ing angklung souvenirs themselves the problem they are facing is a lack of labor because many are resign-ing, another problem is how they as craftsmen can create angklung as a souvenir with a time that is not too long for production and sales to increase. Also, the craftsmen were very lacking in developing their businesses because entrepreneurial competencies were less applied, the craftsmen only waited for customers and were less motivated to work harder. The real conditions in the field show that the angklung craftsmen of Saung Udjo worked on making angklung and souvenirs if there were only orders and the number of orders for the year had recently declined because there were already many angklung craftsmen suppliers other than Udjo's saung angklung. This condition resulted in a lack of motivation for craftsmen to make angklung, the existing problems must be addressed immediately because the creative economy is one of the most effective ways to preserve an infinite number of archipelago cultures. For example, it is like batik or music that is traditional in value or basic but has a contemporary spirit that can be known globally [6].

There are some strategies to solve business performance problems. One of them is entrepreneurial competence. According to the theory of S. Anil Kumar, who said that one's competence is the basis of someone who allows them to issue superior performance in their work and competence This is a characteristic of someone who showed effective results and superior job performance [7]. Reference [8] also explained that competence is a basic characteristic of a person who allows him to provide superior performance in a particular job, role, or situation.

Based on previous research, it was found that competence is the basic characteristic of a person in the form of basic knowledge, ability, and experience that can affect the performance of that person [9]. According to [10] In Research, Entrepreneurship Competence is a Factor in addition to the Entrepreneurship Strategy that Supports Business Performance. Competencies are related to the performance, competitiveness, growth, and success of the company [11].

According to [12], entrepreneurship competency is also a mediation in the relationship between entrepreneurial characteristics and business performance. Entrepreneur-ship competency is an important factor that every entrepreneur needs to have. Therefore, to improve business performance, craftsmen need competencies to manage and achieve business goals [7].

Among some influential factors, entrepreneurial motivation can also influence one's business performance, based on David Mc Clelland's achievement motivation theory. This is based on the theory stated in [13] and [14]. The motivation for achievement in the theory of David Mc Clelland is classified based on the results of activity in the form of accomplishments, including work. The need for achievement is a motivation in carrying out work based on research [9].

Achievement motivation is one of the driving factors for achieving success in competing with a set of performance standards [13]. They have a strong desire for feedback on their achievements. People like trying to get satisfaction in doing better things. High achievement is directly related to high performance.

The relationship between entrepreneurial competence and entrepreneurial motivation with business performance is explained in [13] regarding the Development of Entrepreneurship and Intrapreneurship Attitudes [15]. Effect of Motivation, Knowledge of Entrepreneurship and Independence on The Entrepreneur's Performance and [10] which states that entrepreneurship is considered to have a dominant influence on business performance. This is also supported [4] which states that small companies that want to develop must have an entrepreneurial spirit; Besides [16] confirms that with an entrepreneurial spirit small businesses owner can outperform their competitors.

Based on the research background, the authors formulated several research formulations, namely how the influence of entrepreneurial competence on the 
performance of angklung craftsmen in Saung Angklung Udjo, how the influence of entrepreneurial motivation on the business performance of Saung Angklung Udjo craftsmen in Bandung City, as well as the influence of entrepreneurial competence and entrepreneurial motivation on performance the business of Saung Angklung Udjo craftsmen in the city of Bandung. The purpose of this study was to determine the effect of entrepreneurial competence on the business performance of Saung Angklung Udjo craftsmen in Bandung City, the influence of entrepreneurial motivation on the business performance of Saung Angklung Udjo craftsmen in Bandung City, and the influence of entrepreneurial competence and entrepreneurial motivation on the business performance of Saung Angklung Udjo craftsmen in Bandung

Entrepreneurship plays an important role in business creation and growth, as well as in the growth and prosperity of the region and nation [14]. All types of entrepreneurial personalities include hard work, but certain other types of business are related to expertise called competencies that arise repeatedly in successful entrepreneurs around the world [17].

Competence is a characteristic of people, which results ineffective and/or superior performance at work. In simple terms, competency is a combination of a collection of knowledge, soft skills, and a suitable cluster of motives/traits, an individual processes to perform tasks assigned effectively and efficiently [7].

Entrepreneurship competencies have several indicators that can influence business performance including 1) Competence to manage a business, 2) competencies to manage $\mathrm{HR}, 3$ ) competencies to manage sales, 4) competence to make business records, 5) competencies to manage finances according to [7].

Motivation can be interpreted as a driving force that causes people to do something or do something because they are afraid of something [9]. This strong motive often decreases when it has reached satisfaction or because it finds failure [18-24]. Dimensions of Achievement Entrepreneurship Motivation theory According to [25,26] in [13], among others: 1) Need for Power or the need for power, 2) Need for Affiliation or need for affiliates, 3) Need for Achievement or often called the need for achievement.

Performance is the result obtained by an organization both the organization is profit-oriented or non-oriented which is produced during a period. Reference [27] more explicitly say that performance is the result of work that has a strong relationship with the organization's strategic goals, customer satisfaction, and economic contribution.

There are several indicators of business performance [28] namely: 1) sales growth; 2) capital growth; 3) additional workforce; 4) market growth and marketing; 5) profit growth

\section{METHODS}

The method used in this study was a survey method or explanatory survey. This method aims to determine the influence between variables by testing hypotheses. The data used are secondary data and primary data consisting of entrepreneurial competency questionnaires, entrepreneurial motivation, and business performance.

The sample in this study were all Saung Angklung Udjo craftsmen in Bandung City, sampling using a saturated sample method, which is a method that takes the entire population. Data collection techniques were carried out in this study through questionnaires and interviews. The data analysis technique used in this research is verification analysis. Verification analysis is used to see the influence of entrepreneurial competencies and entrepreneurial motivation on business performance [29].

The variables in the study consisted of entrepreneurial competence, entrepreneurial motivation, and business performance. This research uses measurement data ordinal scale. The scale attempts to measure the meaning of an object or concept for the respondent.

\section{RESULTS AND DISCUSSION}

Entrepreneurial competence (X1) and entrepreneurial motivation (X2), while for the dependent variable is business performance (Y). To determine the effect of entrepreneurial competence on business performance, the effect of entrepreneurial motivation on business performance, and entrepreneurial competence and entrepreneurial motivation on business performance multiple linear regression testing was conducted.

The multiple regression equation models that will be formed in this study are as follows (1).

$\mathrm{Y}=\mathrm{a}+\mathbf{b}_{1} \mathbf{X}_{1}+\mathbf{b}_{2} \mathbf{X}_{2}+\mathrm{e}$

where:

$\mathrm{Y}=$ Dependent variable (business performance)

a $\quad=$ Constant

$b_{1} b_{2}=$ Regression coefficient

$\mathrm{X}_{1}=$ Independent variable (entrepreneurship competence)

$\mathrm{X}_{2}=$ Independent variable (entrepreneurship motivation)

e $\quad=$ Standard Error

Based on the results of data processing through SPSS 24.0 for windows, multiple linear regression coefficients are obtained as follows. 
Table 2. Model summary correlation coefficient

\begin{tabular}{|c|c|c|c|c|c|}
\hline \multicolumn{6}{|c|}{ Coefficients $^{\mathrm{a}}$} \\
\hline \multirow[t]{2}{*}{ Model } & \multicolumn{2}{|c|}{$\begin{array}{l}\text { Unstandardized } \\
\text { Coefficients }\end{array}$} & \multirow{2}{*}{\begin{tabular}{|c|}
$\begin{array}{c}\text { Standardized } \\
\text { Coefficients }\end{array}$ \\
Beta \\
\end{tabular}} & \multirow[t]{2}{*}{$t$} & \multirow[t]{2}{*}{ Sig. } \\
\hline & $B$ & Std. Error & & & \\
\hline (Constant) & 5,242 & 5,424 & & 966 & 342 \\
\hline \begin{tabular}{|l|} 
Entrepreneurship \\
Competence
\end{tabular} & ,206 &, 112 &, 283 & 1,838 & ,077 \\
\hline $\begin{array}{l}\text { Entrepreneurship } \\
\text { Motivation }\end{array}$ &, 513 &, 143 &, 551 & 3,586 &, 001 \\
\hline
\end{tabular}

Based on Table 2 in column B, there are constant values and multiple linear regression coefficients for independent variables. Based on these values, it can be determined that multiple linear regression models are expressed in the form of equations as follows:

$$
Y=5,242+0,206 X_{1}+0,513 X_{2}
$$

From the multiple linear regression equation above, it shows that the regression coefficient of entrepreneurial competence (b_1) is positive. This shows the direction of the relationship of positive equations that illustrate the existence of a positive relationship, meaning that entrepreneurial competencies are in line with business performance. It can be said that if entrepreneurial competencies increase, the business performance will increase, and vice versa, if entrepreneurial competency decreases, then business performance will decline.

The regression coefficient on the entrepreneurial motivation variable (b_2) is positive. This shows the direction of the relationship of positive equations that describe the existence of a positive relationship, meaning that entrepreneurial motivation has a relationship in line with business performance. It can be said that if entrepreneurial motivation increases, then business performance will increase, and vice versa, if entrepreneurial motivation decreases, then business performance will decline.

To find out the percentage effect of X_1 and X_2 on $\mathrm{Y}$, the coefficient of determination can be known by the formula put forward Riduwan (2013: 136) shows as formula (2).

$\mathrm{KD}=\mathrm{r}^{2} \times 100 \%$

where :

$$
\begin{aligned}
\mathrm{KD} & =\text { Coefficient of determination } \\
\mathrm{r} & =\text { Correlation coefficient }
\end{aligned}
$$

The influence of entrepreneurial competencies on business performance can be seen from the results of Table 3.

Table 3. Partial Determination Coefficient

\begin{tabular}{|c|c|c|c|c|}
\hline \multicolumn{5}{|c|}{ Model Summary $^{\mathbf{b}}$} \\
\hline Model & $\boldsymbol{R}$ & $\boldsymbol{R}$ Square & $\begin{array}{c}\text { Adjusted } \boldsymbol{R} \\
\text { Square }\end{array}$ & $\begin{array}{c}\text { Std. Error of the } \\
\text { Estimate }\end{array}$ \\
\hline 1 &, $587 \mathrm{a}$ &, 344 &, 321 & 5,616 \\
\hline
\end{tabular}

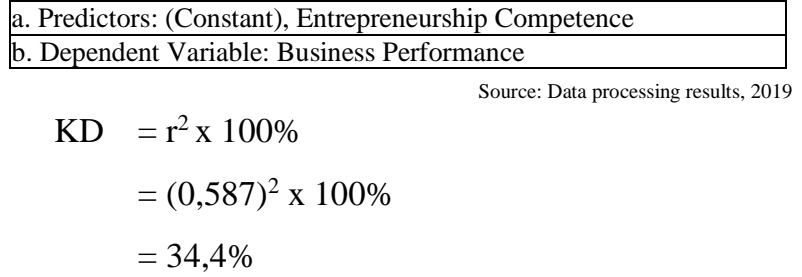

The number of the correlation coefficient $(\mathrm{R})$ is 0.587. This means that the relationship between entrepreneurial competence and business performance is 0.587 . From these numbers, if interpreted it can be concluded that the relationship between entrepreneurial competencies and business performance is moderate.

Then obtained a KD value of $34.4 \%$ which shows the meaning that entrepreneurial competence has a partial effect of $34.4 \%$ on business performance. While the remaining $65.6 \%$ is influenced by factors not examined in this study, such as basic knowledge, ability, and experience that can affect the performance of the person [9].

The influence of entrepreneurial motivation on business performance can be seen from the results of Table 4.

Table 4. Partial Determination Coefficient

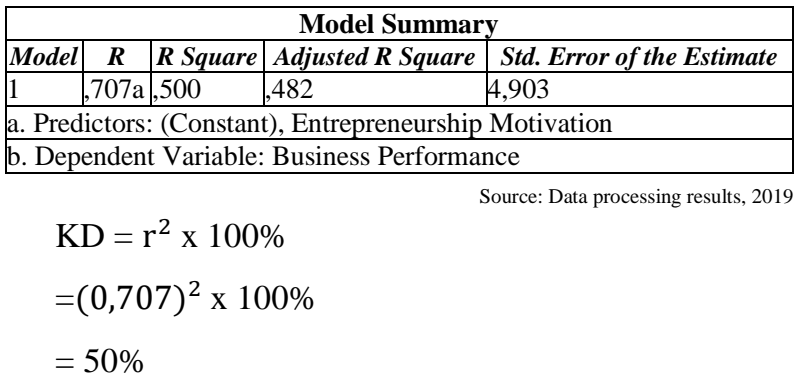

The data above showed the number of the correlation coefficient $(\mathrm{R})$ is 0.707 . This means the relationship between entrepreneurial motivation and business performance is 0.707 . From these figures if interpreted it can be concluded that the relationship between entrepreneurial motivation and business performance is moderate.

Then, a KD value of $50 \%$ shows the meaning that entrepreneurial motivation has a partial influence of 50\% on business performance. While the remaining $50 \%$ is influenced by factors not examined in this study, such as basic knowledge, ability, and experience that can affect the performance of the person (Mulyadi, 2010)

The influence of entrepreneurial competence and entrepreneurial motivation on business performance can be seen from the results of Table 5 .

Table 5. Simultan coefficient of determination

\begin{tabular}{|l|c|l|l|l|}
\hline \multicolumn{4}{|c|}{ Model Summary $^{\mathbf{b}}$} \\
\hline Model & $\boldsymbol{R}$ & $\boldsymbol{R}$ Square & Adjusted $\boldsymbol{R}$ Square & Std. Error of the Estimate \\
\hline 1 &, $746 \mathrm{a}$ &, 556 &, 523 & 4,707 \\
\hline
\end{tabular}




\begin{tabular}{|lll|}
\hline a. Predictors: (Constant), Entrepreneurship & Motivation, \\
Entrepreneurship Competence & \\
\hline b. Dependent Variable: Business Performance & \\
\hline
\end{tabular}

$\mathrm{KD}=\mathrm{r}^{2} \times 100 \%$

$$
\begin{aligned}
& =(0,746)^{2} \times 100 \% \\
& =55,6 \%
\end{aligned}
$$

The number of the correlation coefficient $(\mathrm{R})$ is 0.746. This means the relationship between entrepreneurial competence and entrepreneurial motivation with business performance of 0.746 . From these figures if interpreted it can be concluded that the relationship between entrepreneurial competence and entrepreneurial motivation with business performance is moderate.

A KD value of $55.6 \%$ indicates that entrepreneurial competence and entrepreneurial motivation have a simultaneous influence of $55.6 \%$ on business performance. While the remaining $44.4 \%$ is influenced by factors not examined in this study, such as basic knowledge, ability, and experience that can affect the performance of the person [9].

The $\mathrm{t}$ statistical test basically shows how far the influence of one explanatory variable / independent individually in explaining the dependent variable. To determine the percentage of the influence of entrepreneurial competence and entrepreneurial motivation on business performance. Then using the SPSS 22.0 for Windows program, the output is as follows table 6.

Table 6. Significant Value t Test

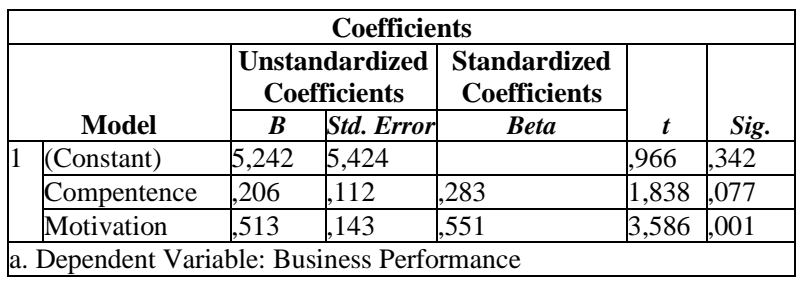

Source: Data processing results, 2019

Based on Table 6 the acquisition of t-count is 1.838 for entrepreneurial competencies and 3.586 for entrepreneurial motivation. Significant level $(\alpha)$ of $5 \%$, and degrees of freedom $\mathrm{df}=\mathrm{n}-\mathrm{k}=30-3=27$ obtained values $t_{\text {tabel }} 2,055$. Because of $t_{\text {count }}>t_{\text {table }}$ or $1,838>$ 1,703 therefore $\mathrm{H}_{\mathrm{a}}$ accepted means entrepreneurial competence has a significant effect on business performance. The value of calculated entrepreneurial motivation is 3.586 .

Because of $t_{\text {count }}>t_{\text {table }}$ or 3,586 $>1,703$ therefore $\mathrm{H}_{\mathrm{a}}$ accepted, means Entrepreneurial motivation has a significant effect on business performance, with the magnitude of the influence of entrepreneurial motivation on business performance.
The F statistic test basically shows whether all independent or independent variables included in the model have a joint effect on the dependent variable. This test is used to test the significance of the influence of entrepreneurial competence and entrepreneurial motivation on the business performance of the $\mathrm{F}$ test formula or ANOVA test described in following table 7 .

\begin{tabular}{|c|c|c|c|c|c|c|}
\hline \multicolumn{7}{|c|}{ ANOVA $^{a}$} \\
\hline \multicolumn{2}{|r|}{ Model } & $\begin{array}{l}\text { Sum of } \\
\text { Squares }\end{array}$ & $d f$ & $\begin{array}{c}\text { Mean } \\
\text { Square } \\
\end{array}$ & $\boldsymbol{F}$ & Sig. \\
\hline \multirow[t]{3}{*}{1} & Regression & 748,765 & 2 & 374,383 & 16,898 &, $000 \mathrm{~b}$ \\
\hline & Residual & 598,201 & 27 & 22,156 & & \\
\hline & Total & 1346,967 & 29 & & & \\
\hline \multicolumn{7}{|c|}{ a. Dependent Variable: Business Performance } \\
\hline \multicolumn{4}{|c|}{$\begin{array}{l}\text { b. Predictors: (Constant), } \\
\text { Enrepreneurship Competence }\end{array}$} & trepreneur & \multicolumn{2}{|c|}{ Motivation } \\
\hline
\end{tabular}

Table 7. Significant Value of F Test

Based on table 7 explains the acquisition of the calculated $\mathrm{F}$ value of 16,898 with p-value ( $\mathrm{sig}$ ) 0,000 . With $\alpha=0.05$ and the degrees of freedom df $2=\mathrm{n}-\mathrm{k}=$ $30-3=27$ and $\mathrm{df} 1=\mathrm{k}-1=3-1=2$, then it can get Ftable 3.35. Due to the value of Fcount> Ftable (16,898> 3.35), then $H_{0}$ is rejected, and $H_{a}$ is accepted, meaning that entrepreneurial competency and entrepreneurial motivation together have a significant effect on business performance.

\section{CONCLUSIONS}

This study conduct is provoked by the needs of broadening the knowledge regarding Halal business using the entrepreneur's perspective. An entrepreneur is an important stakeholder in Halal industry through fulfilling the increasing global Halal demands with Halal product and service. Taiwan is one of the countries now passionately exploiting the business opportunities from Halal industries, even though its knowledge level of Muslim is still developing. Confirming that Halal business can bring the competitive advantage for the firms, a conceptual model with five latent variables is developed in this study to seek what factors can influence the firms in Taiwan to engage in Halal business.

From the findings, the firm's decision to engage in Halal business can be influenced by the firm's understanding of Halal usefulness (i.e. Halal Perceived Usefulness). In addition, there are two other factors that can influence the generation of firm's understanding of Halal usefulness, namely the internal and external firm conditions. The pressures coming from the external environment in this study is represented by the market, government and the Halal trend industry. The way of external firm condition affects the generation of HPU can also be partially mediated with the ID.

This study result is motivated to provide the managerial recommendations for Taiwan pursuing the 
Halal ecosystem. There are two recommendations the authors offered. First, realizing HPU role to influence the firm's decision for engaging in Halal business, the authors recommend that the Taiwanese governments should pay more attention to any attempts for generating this firm's understanding about Halal usefulness in terms of the Halal value and the benefits the firms can obtain in the competitive landscape. For Taiwan case, to strengthen the relationship and coordinate more with Halal certification bodies in Taiwan can be the effective way to enhance the HPU in the firm. When considering Taiwan as a country with a Muslim minority, the dissemination of Muslim information cannot be as extensive as it is in Muslim-majority countries. Muslims I. in Taiwan should concentrate their expertise in Halal certification bodies.

Second, the authors also contribute by giving a picture of what managers should do in a way of performing Halal business. This study provides the internal firm condition need to be pursued, such as good assets (i.e., physical, financial, human resource), innovation climate and R\&D competence. This set of internal firm condition can potentially lead the firms in Taiwan doing Halal business.

Regardless of its contributions, this study has four shortcomings that could be addressed as suggestions for further studies. Firstly, the authors only considered the influence of general external stakeholders. Even though it can present normative impact through an institutional theory lens, the Halal certification body was not included in the external driver. Secondly, due to budget and time constraints, the total data of 41 responses may be reduced, preventing the authors from performing more rigorous data analysis. For further research, it would be preferable to increase the number of respondents in order to obtain better results and present a larger population of Halal businesses in Taiwan. Thirdly, the authors did not specify the markets aimed by the firms, i.e. domestic or international market. Therefore, this study cannot cover further explanation about Halal business phenomenon regarding the market orientation. Fourthly, moderating effect of Islamic knowledge to generate HPU can be included in future researches.

\section{REFERENCES}

[1] D. Losonci and K. Demeter, "Lean production and business performance: international empirical results," Compet. Rev., 2013, doi: 10.1108/10595421311319816.

[2] M. Taghian, C. D’Souza, and M. J. Polonsky, “A stakeholder approach to corporate social responsibility, reputation and business performance," Soc. Responsib. J., 2015, doi: 10.1108/SRJ-06-2012-0068.
[3] G. Schiuma and G. Schiuma, "Managing knowledge for business performance improvement," J. Knowl. Manag., 2012, doi: 10.1108/13673271211246103.

[4] Y. Al-Ansari, S. Pervan, and J. Xu, "Innovation and business performance of SMEs: The case of Dubai," Education, Business and Society: Contemporary Middle Eastern Issues. 2013, doi: 10.1108/EBS-042013-0012.

[5] UMKM Provisinsi Jawa Barat. Kementerian Koperasi dan Usaha Kecil dan Menengah. Januari 10, 2018. [Online]. Avaible: www.depkop.go.id

Ari, and H. Mulyadi, "Pengaruh Keterampi-lan Wurausaha terhadap Keberhasilan Usaha," vol. 1, no.1, pp. 213-223, 2016.

[6] S.A. Kumar, and N. Suresh, Operation Management. New Delhi: New Age International (P) Ltd., Publisher, 2009.

[7] P. Marshall, People and Competencies. 2007.

[8] H. Mulyadi, "Pengaruh motivasi dan kompetensi kerja terhadap produktivitas kerja karyawan pada PT. Galamedia Bandung perkasa," Manajerial., vol. 9, no. 17, pp. 97-111, 2010.

[9] N.A. Muslikah, A.T. Haryono, and C. Harini, "Pengaruh kompetensi entrepreneurial, strategi kewirausahaan dan modal sosial terhadap keunggulan kompetitif berkelanjutan dengan kinerja usaha (pengusaha) sebagai variabel intervening (Studi kasus UKM mebel di Desa Kembang Kab. Jepara)," J. Manage., 2018.

[10] F. Maad, L. Humaira, and H. Susanto, “Kompetensi kewirausahaan pelaku industri rumah tangga pangan lokal di Kabupaten Bogor,” SENASPRO., 2017.

[11]E.N. Utami, E, and H.D. Dwi, "Pengaruh kompetensi kewirausahaan terhadap kinerja UMKM," vol. 4, no.1, pp. 642-651, 2017.

[12] Winarno, "Pengembangan sikap entrepreneurship \& sikap intrapreneurship: korelasinya dengan udaya perusahaan, gaya kepemimpinan, dan motivasi berprestasi di perusahaan / Winarno," vol. 1, 2011.

[13]R.D. Hisrich, M.P. Peters, and D.A. Shepherd, Entrepreneurship. Tenth Ed. McGraw-Hill Education. 2016.

[14]Julita, "Pengaruh motivasi, knowledge of entrepreneurship dan independensi terhadap the entrepreneur's performance(Studi kasus pada UKM di Kota Medan).," J. Manaj. Bisnis, 2013.

[15] S.M. Carraher, J.K. Buchanan, and G. Puia, "Entrepreneurial Need for Achievement in China, Latvia, and the USA,” Balt. J. Manag., 2010. 
[16] J.R Baum, M. Frese, R.A. Baron, and J.A. Katz, "Entrepreneurshipmas an area of psychology study: An introduction," The psychology of entrepreneurship., pp. 41-65, 2007.

[17] A.C. Hemingway, Corporate Social Entrepreneurship. $1^{\text {st }}$ Ed. Cambridge University Press. 2013.

[18] M. Casson, W.P.J. Buckey, K. Dark, M.D. Giusta, A. Godley, M.A. Gulamhussen, N. Wadeson, T.D.S. Lopes. Entrepreneurship: Theory, networks, history. 2010.

[19]D. Smallbone, H. Landström, and D. Jones-Evans, Entrepreneurship and Growth in Local, Regional and National Economies: Frontiers in European Entrepreneurship Research. 2009.

[20]F. Bill, B. Bjerke, and A.W. Johansson, (De)mobilizing the entrepreneurship discourse: Exploring entrepreneurial thinking and action. 2010.

[21] M. Scherdin and I. Zander, “Art entrepreneurship: An introduction," Art Entrepreneurship. 2011.

[22] M. Farhangmehr, P. Gonçalves, and M. Sarmento, "Predicting entrepreneurial motivation among university students: The role of entrepreneurship education,” Educ. Train., 2016.

[23]H. Oosterbeek, M. van Praag, and A. Ijsselstein, "The impact of entrepreneurship education on entrepreneurship skills and motivation," Eur. Econ. Rev., 2010.

[24] D.C. McClelland, The Achieving Society. NY: Van Nostrand. 1961.

[25]D.C. McClelland, Human Motivation. NY: Cambridge University Press. 1985.

[26]M. Armstrong and D. Brown, "Relating Competencies to Pay: The UK Experience," Compens. Benefits Rev., 1998.

[27] R. Purwaningsih and P. Kusuma Damar, "Analisis faktor- faktor yang mempengaruhi kinerja usaha kecil dan menengah (ukm) dengan metode structural equation modelling (studi kasus UKM berbasis industri kreatif Kota Semarang)," Pros. SNST Fak. Tek. Univ. Wahid Hasyim Semarang, 2015.

[28] Sugiyono, Metode Penelitian Kuantitatif, Kualitatif dan $R \&$ D. Bandung: Alfabeta. 2017. 